\title{
THE SCIENCE OF LAW REGARDING NEW LEGAL CONTRACTUAL COMMERCIAL INSTITUTIONS FROM THE POINT OF VIEW OF THE CONTINENTAL CIVIL LAW SYSTEMS: THE SPANISH AND GERMAN EXAMPLES
}

\author{
Juan Palao-Uceda*
}

\begin{abstract}
This article tries to return to the essence of civil law which, with a little more than ten key contractual institutions, allows all disputes created from newly founded institutions to be examined and interpreted. If law is science it must be able to be reduced to a set of basic concepts that have been coined and concluded from daily contractual practice and, almost in their entirety, have been in force over time. Hence the study of Roman law and Roman legal tradition remain a constant reference to our continental law. However, this does not prevent them from being open to gradual enrichment.
\end{abstract}

Key words: science of law, Roman Law, codification, civil law, new contracts

\section{INTRODUCTION}

All science has built its knowledge through observation and the creation of concepts that encompass and embrace the reality in which it studies. Through these concepts, all the information provided by science is stored and synthesised, helping it to be studied and, especially, to be applied.

The simple memorization of information from case studies, without the creation of concepts, does not allow the proper storage or use of the knowledge obtained ${ }^{1}$, since so much knowledge is dispersed.

* PhD, Faculty of Legal and Business Sciences - Francisco de Vitoria University, Madrid - Spain. 
The scientific method has the following stages:
A) Observation
B) Background research
C) Hypothesis
D) Design an experiment
E) Confirmation
F) Creation of the theory and concept.

To illustrate this, we set the following example:

A) - We see horns on an animal and we see that they are pointed, sharp and hard.

B) - Background research. We think about their function and observe that the animals that have them usually have muscular necks to support and attack with them.

C) - Hypothesis. We believe they can be an attack/defense weapon possessed by certain animals.

D) - Design an experiment. We do a test and we approach it with a bait that the animal (bull or rhino) immediately charges with its horns.

E) - Confirmation. We confirm our hypothesis that it is already a theory.

F) - We build the concept of horn as a "weapon of the animal world".

The creation of the horn concept, regardless of the animal that has it, allows us to identify them and to notice their potential danger although it is present in diverse species and under diverse morphologies and forms.

Although there are obvious exceptions (cow), those animals that have horns (bull, buffalo, goats, rhinoceros, etc.) use them as an offensive/defensive weapon. Having that concept tells us a lot about new creatures we see.

Without this abstract concept of "horn" we would be forced to memorize each specific animal in order to appreciate their predictable behaviour and aggressiveness, which would require a vast memory of case studies and, therefore, prevent us, a priori, from anticipating a possible new danger in an unknown animal with horns. In addition, in any case we would need a general concept of each animal to organise the information.

1 Rudolf von Ihering, Geist des römischen Rechts auf den verschiedenen Stufen seiner Entwicklung, Leipzig: Zweiter Teil, 1858, 342. 
With this crude example, we indicate the importance of creating general classifications or concepts to simplify and understand a new reality. Concepts are tools to analyse new cases. Through them we are capable of bringing light to new reality.

Hence, with this concept of "horn" we can move through the animal world and separate ourselves from those animals that have this weapon as a precaution because we are aware of their functionality even if we do not know the specific animal in question.

The construction of concepts (by separating general knowledge from the uncountable casuistry ${ }^{2}$ ) helps to guide us on many other occasions, with other animals (bull, elephant, ...) even if we do not know them in advance and use this conceptualised knowledge in new countless situations and with animals that apparently would have nothing to do with each other.

This helps us to identify it in its different forms, colours and positions and to warn us of the danger we can be in. Through this concept we store information that we can then retrieve and use for many other situations.

Without conceptualization there is no creation of general classes to archive substantial case studies, which can cause us to lose ourselves in a casuistic ocean of unfathomable information. Without creating general classes or concepts there is no possibility of archiving knowledge. Finally, science is not possible without this file, as a gradual accumulation of knowledge because there would only be an extensive list of cases with no connection to each other. This prevents knowing the reality.

The science of law takes part in this creation of general concepts. In particular, we will see how civil law systems apply this scientific method to new and unknown contractual institutions.

\section{THE SCIENTIFIC CREATION OF LAW IN LAW CIVIL}

\subsection{The basic contractual figures of the codification movement of civil law}

The nineteenth-century codification in Europe sought, as a priority, the same thing, to condense all the legal knowledge of the time (already

2 Ibidem, 342. 
largely derived from Roman law ${ }^{3}$ ) into codes to systematize and order it for legal security.

Civil law has Law as its main source and basis, a law that has been embodied in a set of codes and is called on to regulate all aspects of the various legal sectors of the system.

The greatest task of the codification or scientific conceptualization of law took place in the nineteenth century and consisted of organising all historical legal knowledge (laws, jurisprudence, doctrine, etc.) into concepts and including them into legal codes. Its task was very reflexive and was based, although it was intended to be based only on reason, on a gradual observation of the business practices that had occurred for centuries in life with their particular problems.

The gradual codification throughout history has, in our system, yielded the various basic contractual legal categories contained in civil codes which have subsequently been reported by the commercial contractual system. In most civil law systems, these basic civil contractual figures are similar despite a few exceptions. In Spain and in Germany they are the following ones:

\begin{tabular}{|c|c|}
\hline $\begin{array}{l}\text { SPANISH CIVIL CODE } \\
\text { 1. - Sales contract (Compraventa } \\
\text { art. } 1445 \text { et seq. Spanish Civil Code - } \\
\text { Cc) } \\
\text { 2. - Barter agreement (Permuta art. } 1538 \\
\text { et seq. Cc) } \\
\text { 3. - Donation (Donación art. } 618 \text { et seq. } \\
\text { Cc.) } \\
\text { 4. - Lease contract (Arrendamiento } \\
\text { art. } 1542 \text { et seq. Cc) } \\
\text { 5. - Co-ownership (Comunidad de } \\
\text { Bienes } 392 \text { Cc) \& Company contract } \\
\text { (Contrato de sociedad art. } 1665 \text { et seq. } \\
\text { Cc) } \\
\text { 6. - Mandate contract (Mandato } \\
\text { art. } 1709 \text { et seg. Cc) }\end{array}$ & $\begin{array}{l}\quad \text { GERMAN CIVIL CODE } \\
\text { 1. - Sales contract (Kauf } \$ 433 \text { et seq. } \\
\text { Bürgeliches Gesetz Buch or German Civil } \\
\text { Code - BGB) } \\
\text { 2. - Barter agreement (Taush } \$ 480 \text { et seq. } \\
\text { BGB) } \\
\text { 3. - Donation (Schenkung } \$ 516 \text { et seq. } \\
\text { BGB) } \\
\text { 4. - Lease contract (Mietvertrag } \$ 535 \text { et } \\
\text { seq. BGB, Dienstvertrag } \$ 611 \text { et seq. BGB) } \\
\text { 5. - Co-ownership (Gemeinschaft } \$ 741 \text { et } \\
\text { seq. BGB) \& Company contract (Gesell- } \\
\text { schaft } \$ 705 \text { et seq. BGB) } \\
\text { 6. - Mandate contract (Auftrag oder Man- } \\
\text { dat } \$ 662 \text { et seq. \& Anweisung } \$ 783 \text { et seq. } \\
\text { BGB) }\end{array}$ \\
\hline
\end{tabular}

3 Roman Law had a deep influence on continental law systems. On the common law system had only an academic influence mainly on Universities. See: María José Falcón y Tella, La jurisprudencia en los derechos romano, anglosajón y continental, Madrid: Marcial Pons, 2010, 59. 


\begin{tabular}{|l|l|} 
S7. - Loan contract (Préstamo art. 1740 & 7. - Loan contract (Darlehen $\$ 488$ et seq. \\
et seq. Cc) & BGB Sachdarlehenvertrag $\$ 607$ et seq. \\
8. - Deposit contract (Depósito & BGB) \\
art. 1758 et seq. Cc) & $8 .-$ Deposit contract (Verwahrungsvertrag \\
9. - Random contracts (Aleatorio & $\$ 688$ et seq. BGB) \\
art. 1790 et seq. Cc) & $9 .-$ Random contracts (Unvollkommene \\
$10 .-$ Settlement contract (Transacción & Verbindlichkeiten $\$ 762$ y ss et seq. BGB) \\
art. 1809 et seq. Cc) & $10 .-$ Settlement contract (Vergleich $\$ 779$ \\
$11 .-$ Guarantee contract (Fianza & et seq. BGB) \\
art. 1822 et seq. Cc), Pledge/mortage & $11 .-$ Guarantee contract (Bürgschaft $\$ 765$ \\
contract (Prenda o hipoteca art. 1857 et & et seq. BGB) \\
seq. Cc) & $12 .-$ Assignment agreement (Abtretung \\
$12 .-$ Assignment agreement (Cesión de & $\$ 398$ et seq. BGB) \\
derechos art. 1526 y ss Cc) & \\
\hline
\end{tabular}

As we see, the main contractual institutions can be found in both civil law systems. Other civil law systems have similar figures as well.

Some civil codes frequently include secondary contracts that can be comprised in one of the aforementioned main categories, e. g. the German gratuitous loan ( $\$ 598 \mathrm{BGB})$ is a loan, a promise to fulfil an obligation ( $\$ 780 \mathrm{BGB})$ is a settlement contract, a pledge \& mortgage (art. 1857 et seq. $\mathrm{Cc}$ ) is a guarantee contract, etc.

Therefore, the secondary contracts, have their roots in the previous and more general civil contractual institution.

We can see how through the use of these basic categories or concepts, which are contained in the civil codes, can be analysed, understood and we can extract the consequences of all new commercial, national and international contractual categories.

Since commercial reality is one of the most dynamic the proliferation of new institutions is constantly happening. The construction of concepts that helps us understand the new contractual categories with the knowledge and extensive legal experience acquired over centuries becomes more pressing than in other branches of law.

The less basic concepts are, the more orderly and structured will the contractual information be $\mathrm{f}^{4}$.

4 Rudolf von Ihering, op. cit., 342-354. 
In fact, according to Roman tradition, all contracts can be included in three or four categories: In our case, share contracts (Company contracts, co-ownerships, etc.), Mandate contracts (Guaranties, Agencies, authorisations, etc.) and transfer contracts. The latter can be broken down into two new categories: Permanent transfer contracts (Barter, Sale, Donation, Loan, etc.) and temporary transfer contracts (Deposit, Lease, etc.) $)^{5}$.

\subsection{The codification movement of civil law and the scientific method.}

In order to see the scientific construction of law it is necessary to go back to the very roots of our present continental legal institutions, to Rome ${ }^{6}$.

Already in ancient Rome, from where much of the legal continental contractual institutions started, the scientist of law and codifier did nothing but transpose into laws the basic institutions that the very daily needs of the traders, had helped to produce 7 .

To see how reality has reported on the creation of our basic contractual institutions we will look at the example of the institution of the pledge contract in ancient Rome.

5 In Rome itself the basic rules were only four, through which it was possible to channel all the business reality. See: William Warwick Buckland, Arnold McNair, Roman Law and Common Law. A comparison in outline, Cambridge: Cambridge University Press, 2008, 279-280. "In Roman law, apart from certain praetorian and later pacts, of relatively small importance, there were only four contracts which were binding by mere consent, and these were, naturally, those most important in everyday comerce, sale, hire, societas (partnership) and the contract of mandatum".

6 Antonio Guarino, Diritto Privato Romano, Napoli: Casa Editrice Dott. Eugenio Jovene, 1966, 5. “...il diritto è un fenomeno sociale, una manifestazione del tutto alogica della storia umana, che bisogna desumere faticosamente dalla realtà, entro cui spesso addirittura si nasconde. L'unico modo per sapere quale esso è, come esso è fatto, come esso opera, dove esso tende consiste nella ricerca storiografica. E questa, si badi, più che una assoluta sicurezza della configurazione del fenomeno, fornisce al giurista la possibilità di creare e affinare, attraverso l'esperienza, una sua acuta "sensibilità del diritto"..."

7 In fact the most important contract of all, the contract for the sale of goods, was a contract whose legal physiognomy was being assessed through the specific stipulations of the parties that, finally, came to make up the rule see: William Warwick Buckland, Arnold McNair, op. cit., 311. "Many of their obligations which were implied in sale in later law had originally been imposed by express stipulations". 
We are told that there were initially no real guarantees to ensure compliance with an obligation. Therefore, purchases and sales were used as fiduciary business (fiducia) for the creditor to obtain a guarantee (the transferred asset) in order to guarantee the due obligation. When the creditor got paid, he resold the asset again to the debtor. However, this figure could lead to the creditor disposing of the asset as the owner, which could lead to abuse.

In view of this need, the figure of the "pignus" was created, which allowed the transfer of a simple right of possession over the asset to the creditor as collateral, but it had many disadvantages. If the guaranteed obligation was not fulfilled by the debtor, the creditor-holder could not sell the asset. Therefore, an agreement was specifically reached so that the creditor has the possibility to sell the given asset or even to confiscate it, in order to get the fulfilment of the non-complied obligation ${ }^{8}$.

The second of the agreements, the one of confiscation, gave rise to many excesses since the creditor sometimes abused that right to keep the asset given as collateral or to value the asset as insufficient to cover all the debt. That is why Constantine expressly ${ }^{9}$ forbids such an agreement so that, in case of default, the asset must be disposed to third parties and the value of the good realised.

This is the current configuration of both the pledge as well as the mortgage in our law system, a guarantee that grants the power of sale to the creditor but without any power to appropriate himself of the property directly ${ }^{10}$.

For all these reasons, codification, far from signifying a denial and withdrawal from reality, was a legislative transposition of the contractual figures created by daily civil and commercial practice. In fact, as it is done according to the scientific method, an inexhaustible casuistry and a very extensive negotiating reality were condensed into simple figures through the inductive method of observation by great jurists, judges, professors, lawyers, and so on.

8 Ibidem, 314-315.

9 Ibidem, 316.

10 Cc Art 1858. It is also of the essence in these contracts that, upon maturity of the principal obligation, the objects constituting the pledge or mortgage may be disposed of to pay the creditor. Article 1859. The creditor cannot appropriate the objects pledged or mortgaged, nor dispose of them. 
Centuries of history, analysis and knowledge of the law have settled into some codes, some of which, after centuries, and with some modification, still remain. In particular, the civil code whose genesis can be traced to Roman law.

But what is said of civil law is no less in mercantile law. Commercial law, in order to create its institutions, had always observed practice, that is to say, "The source of commercial Law does not produce Law: it limits itself to discovering it, inventing it, acting it out"11.

The contract for a current bank account, credit card, supply, factoring, etc. and many others have been created by practice and, in these cases, not even the legislator has yet transposed them into legal precepts. It is the practice that generates the right due to the negotiating needs although later the law, in some cases, sanctions it ${ }^{12}$.

Like the scientists who analyse nature, in the commercial sphere, the legislator goes like Moses to Mount Sinai. He went up so that the ten commandments were handed over to him. The civil and commercial legislator looks at the uses and practices of traders to promulgate their standards. Thus most commercial rules have been informed by reality itself and its consequential needs.

That is why we have to say with Garrigues that "Commercial law is not created legislatively, but by the force of use. The rapid course of trade demanded a preferential elastic Law that would conform to the slightest nuances of ever changing needs: a dynamic Law, alive in practice." 13 .

In this sense it goes without saying that, almost no current commer$\mathrm{cial} /$ civil code has introduced yet such contracts as factoring, confirming or leasing. These were spontaneously created by practice and needs of traders. Therefore, even today, remain atypical ${ }^{14}$.

11 Joaquin Garrigues, Curso de Derecho Mercantil, Madrid: S. Aguirre, Madrid, 1936, 74. "La fuente del Derecho mercantil no produce Derecho: se limita a descubrirlo, a inventarlo, a exteriorizarlo".

12 In the case of Spain, a commercial code is in the process of being approved, which seeks to typify all those contractual rules that the commercial practice has been generating based on the daily needs of businesses.

13 Joaquin Garrigues, op. cit., 89.

14 For example, neither the Spanish nor the German contemplate these figures. The Polish Civil Code regulates it in art. 7091, but new figures are beginning to fill in for this contract. 
But the situation of commercial law is different from that of civil law. Indeed, if the majority of the continental system is called "Civil law" this is because it is based on civil law.

According to Garrigues «[...] concepts for civil law are arrival points, for mercantile law they are starting points $\rangle^{15}$. As we will see, although the mercantile reality is more bustling and at every step is creating new figures, these can be explained through the basic civil figures, adapted to the specialities of commerce.

In this way civil law can bring order and provide an instrument of analysis to the current huge, tangled, superabundant and warped business relationships.

Just as the scientist of nature identifies the law of gravity in various phenomena such as a waterfall, falling objects or the curved trajectory of every projectile, so the law scientist discovers the contract of sale with nuances in a commercial supply ${ }^{16}$, exclusive distribution contract, etc.

Concepts both, generic and unitary, help us to analyse reality, classify it and predict the effects connected to it.

Because the negotiating reality in civil law can be condensed into those basic generic categories, these, over time, through practice, jurisprudence and doctrine, are enriched and made explicit, gradually improving our legal knowledge.

The commercial aspect of this reality, due to the dynamism of the economic environment, has put together, improved these figures to adapt them to commercial contractual reality but commercial contracts can only be understood if we study them in the light of the simple concepts of the civil code.

Codification of law is one of the circumstances that allow law to be called science, that is to say, the creation and the increase of a growing knowledge of the commercial legal reality.

15 Joaquin Garrigues, Curso de derecho Mercantil, Madrid: Silverio Aguirre Torre, Vol. II, 35.

16 Rafael Natera Hidalgo, Fiscalidad de los contratos civiles y mercantiles, Madrid: Wolters Kluwer, 2012, 187.”...el contrato de suministro no presenta prácticamente diferencias desde el punto de vista fiscal con la compraventa de bienes muebles efectuado por un empresario". 
It is not that current institutions are forgotten as time goes by. It is more that they are combined to meet contemporary contractual needs ${ }^{17}$.

If the legal system and fundamental contractual institutions were completely different in each historical period, not subsumable under basic categories, one could not make law science ${ }^{18}$ since today's knowledge would not be valid for tomorrow's legal system.

It is as if we were to say that the natural order and its laws from time to time radically change so that gravity would no longer exist, the electromagnetic force would be replaced by another force, the molecular structure of the atom would be transformed, and so on, so that all our books, our research and knowledge of the previous reality would have to be thrown away from time to time.

This is not so in physics or in law, that is why both are sciences. Both natural laws and basic human form and rules remain unchanged in their basic but constantly evolving lines.

Although hundreds of years have passed, properties are still being sold, objects are still being leased, services being rendered, etc. although technology allows a sale to be made by electronic means and we may be talking about web domains when before we only talked about commercial names, patents and trademarks.

Unlike what Kirchmann said in "Jurisprudence is not science", when he asserted that "drei berichtigende Worte des Gesetzgebers und ganze Bibliotheken werden zu Makulatur (three rectifying words of the legislator and whole libraries become rubbish)" ${ }^{\prime \prime}$, legal knowledge accumulated over years

17 Rudolf von Ihering, op. cit., 360. "Diese Bewegung ist aber eine unübersehbar reiche, ewig neue und produktive; jeder Tag bringt neue Worte, jeder Tag neue Rechtsverhältnisse. Aber bei letzteren wie bei ersteren ist dieser Reichtum und diese Verschiedenheit nur das Produkt einer Kombination einfacher Elemente, und hierauf beruht, wie bei der Sprache, so auch beim Recht, die Möglichkeit einer verhältnismäßig leichten Beherrschung der Sache”.

18 That is why the Romans insist that the science of law can only be to look to the old to history, indicating in some way that the old, possibly under other appearances is still valid. See: Antonio Guarino, op. cit., 5-6. "Lo studio del diritto culmina, in conclusione, nello studio storiografico del diritto. "Scienza del diritto" significa storiografia giuridica. Naturalmente, le tematiche e le accentuazioni possono essere diverse, ma il fine ultimo è sempre quello di una conoscenza e valutazione critica del fenomeno giuridico".

19 Julius von Kirchmann, Die Wertlosigkeit der Jurisprudenz als Wissenschaft, Darmstadt: Wissenschaftliche Buchgesellschaft, 1973, 25. 
has distilled basic contractual categories that, enriched by law, doctrine and jurisprudence, are now the light to interpret the new contractual reality.

In fact, all civil codes, since their promulgation, have experienced no substantial modifications within the basic contracts.

We think that the science of law has, like any other science ${ }^{20}$, a common nucleus that is regularly increasing despite certain fluctuations and new fields that are constantly opening up. A fluctuation similar to that produced in the field of physics in which the theory of relativity evolved from the basis of Newtonian mechanics.

But both the scientist of nature and the scientist of law must use the knowledge assessed over centuries to analyse the new reality this foundation will always remain valid and will continually be enriched, in spite of the technological, social and economic changes ${ }^{21}$.

\section{HOW CIVIL LAW SYSTEMS DEAL WITH THE NEVERENDING CREATION OF NEW CONTRACTS}

\subsection{The codification and constant genesis of commercial law}

As was said, commercial law is not created by the great knowledge of a legislator who anticipates reality, but from negotiating needs (expressed in the form of uses and practices of trade), which continuously develop contractual institutions. To this we attribute the triumph of the Vienna convention for the sale of goods. Compared to the attempts of its predecessors, this assimilation of the reality of commercial practice adapts to the real needs of traders ${ }^{22}$.

20 Quintus Mucius Scaevola, Civil code. Commentary, Madrid: Instituto editorial Réus, 1949, Vol. I, 40. “...ciencia de la legislación...”.

21 Quintus. Mucius Scaevola, op. cit., Vol. XX, 463. "La vuelta al pasado no es una repetición exacta de lo que ha sido, sino una repetición modificada. Puede comparársela a la segunda edición de una obra que, conservando sus caracteres fundamentales, se enriquece con todas las nociones adquiridas y los descubrimientos realizados durante el tiempo transcurrido entre la primera y segunda publicación."

22 Tomás Vázquez Lépinette, Compraventa Internacional de Mercaderías. Una visión jurisprudencial, Navarra: Editorial Aranzadi, 2000, 36-37. 
It is thus that the commercial laws are being defaced before the new creations of the commercial practice. In fact, the Spanish commercial code, along with other codes, has been overtaken by reality and, in the mercantile sphere, many of the figures that regulate commercial relations are atypical, that is, they are not included in the codes.

This is the case of Factoring, with or without recourse, confirming, franchise agreements, leasing, documentary credit, Joint Venture, stock options, etc.

That is especially true in the Anglo-Saxon countries where the proliferation of new contractual figures has been more lavish in merit to greater inventiveness and commercial activity.

Before such an overflow and dynamic contractual genesis due to actual commercial use, we could think that the codes are a hindrance for the adaptation of the system to reality and an outdated inefficient instrument of no utility.

That is far from the truth. The continental codification effort that was condensed into the knowledge codes of many centuries and which, as we said, managed to bring order and generated a true legal system as a complete and coherent integrated set of rules ${ }^{23}$, was not a waste of effort.

In fact, the codes and especially the civil nuclear code that all the basic contractual institutions include, constitutes a very important instrument of integration and hermeneutics of any contract in civil law systems as we will see below in the Spanish case.

\subsection{Codification as a hermeneutical and analytical instrument of increasing contractual case studies}

As we have said, the scientist, through general laws, explains the functioning of nature, he succeeds in dissecting and analysing case studies, categorising them to avoid or favour their causal chains despite their multiform external manifestation.

23 Completion is related to the ability of a legal system to solve all the issues that arise. On the other hand, coherence tells us that the solutions to similar cases will be identical and similar, without contradictions in the solution of the disputes. See: María José Falcón y Tella, op. cit., 60. 
E.g. Through the knowledge that botany gives us about the germination of roses, we can plant and reproduce specific circumstances to grow them. On the other hand, through the agent that causes a virus, we can develop a vaccine to avoid its incubation and/or proliferation.

The contractual relationships are normally found in the form of complex combination ${ }^{24}$ too.

Therefore, the scientist of law should analyse, separate and define the basic law institutions ${ }^{25}$. The less institutions there are, the better, as they can be used and recognized easier ${ }^{26}$.

Likewise, by identifying the different contractual classes in legal relationships, we can determine the consequences of these commercial relationships, already contained and systematised in univocal legal knowledge. We use them, avoid them and/or apply them in the future.

Since a contract, on many occasions, can not give us all the exegetical keys due to the plurality of circumstances and problems that may occur, it is necessary, in order to overcome a dispute, to have a list of concepts already studied and assessed, which throw a light on the consequences, effects and scope of the relationships. This favours the speed of contracting and avoids endless contracts that, in essence, make contracting difficult and turn agreement into extremely complex instruments.

All of the core contracts of the codification are included in the Spanish/German civil code and, based on these, all of the mercantile contracts that, due to their dynamic mercantile life, are then created and can be analysed, interpreted and clarified.

Thus, the basic contracts of the civil law system discussed above and their regulation can clarify and limit newly created contracts.

Since basic figures are extensively dealt with by law, jurisprudence, and doctrine, these help to interpret, complete ${ }^{27}$, and fit into all the rules that contain them.

24 Rudolf von Ihering, op. cit., 343.

25 Ibidem, 363.

26 Ibidem, 342 and 354.

27 The civil law system is meant to be complete. M.J. Falcón y Tella, op. cit., 63 and 111. 
For this reason, a Leasing contract is made up of a lease agreement, a contract for the transfer of the purchase right, loan contract and/or a sales contract where applicable ${ }^{28}$.

In the event that disputes arise as to how to apply/interpret the contract, we can use the extensive regulations, jurisprudence and doctrine on the lease, loan or on the sale, so that, even if there are no judicial precedents, by analogy $y^{29}$ there is already an extensive handling of the contracts involved that help us to clarify the rights and obligations of the parties. However the mixture of contracts represents a new figure, in which sometimes prevails the lease provisions, loan provisions or the sale provision $s^{30}$.

According to the German High Court resolutions regarding the leasing contract could also consist of a contract for the sale of goods and a Loan contract (granted by the leasing company) ${ }^{31}$, where the tenant wats to buy the asset from the very beginning.

The same would happen with a renting contract as it would be a lease agreement for an asset and lease of services ${ }^{32}$, to which a random contract can be added if the renting entity deals with all the problems and contingencies that may occur to the leased object.

In fact, the lease of goods and services, according to Roman law, integrated the same family of contracts. It probably had to do with the fact

28 Resol. of BGH (Bundesgerichtshof or German Supreme Court) 29th November 1995 (VIII ZR 32/95) \& 4 Februar 2004 (XII ZR 301/01).

29 See: María José Falcón y Tella, op. cit., 112. Resol. of BGH 26th November 2014 (XII ZR 120/13).

30 When mixing up the contract for the sale of goods and leasing agreement can not be applied all the provisions as the same time. Therefore, depending on the particular situation the rules regarding one of the two contracts shall prevail, sometimes even against the contract' stipulations (Resolution of BGH 21th December 2005 (VIII ZR 85/05)).

31 Resol. of BGH 26 November 2014 (XII ZR 120/13) \& 4 February 2004 (XII ZR 301/01).

32 Rafael Natera Hidalgo, op. cit., 1049-1050. "En relación a su naturaleza jurídica hay que decir que de acuerdo con su propia definición es un contrato de arrendamiento de bienes, normalmente de equipo, que se efectúa por períodos usualmente cortos conectados con una prestación de servicios por parte de la empresa arrendadora, a fin de que el uso del bien por el arrendatario sea perfecto a lo largo de la vida del contrato." 
that the slaves were leased at that time as if they were things ${ }^{33}$. Nowadays, a lawyer, doctor, expert, etc. leases himself (his knowledge, skills, etc.) to the "tenant" in order to render a service in a similar manner.

Therefore there are some rules of law that can be applied to both figures $^{34}$. A cheque would be a mandate given to a bank to pay the bearer or beneficiary thereof and a prior deposit agreemen ${ }^{35}$.

A documentary credit would be a joint guarantee contract.

A franchise agreement would normally be a temporary assignment (lease) of (trademark) rights ${ }^{36}$, a Spanish/German lease of services ${ }^{37}$ provided by the franchisor to the franchisee to start up the business and a supply contract between the franchisor and the franchisee, since the former usually provides the raw materials or the goods ${ }^{38}$ that must be sold. The confirming rule would be a payment mandate given by the debtor (customer) to the confirming entity, to pay their debts. At the same time there is a loan for their payment by the confirming entity, which is settled periodically. But as we say for other figures this may vary, depending on what is agreed upon and, therefore, there may be other figures involved ${ }^{39}$.

33 Monika Anders, Burkhard Gehle, Das Recht der freien Dienste Vertrag und Haftung, Berlin: Walter de Gruyter, 2001, 2.

34 Rudi Müller-Glöhe, "Commentaries on $\$ 611$ ”, In: Münchener Kommentar zum Bürgerlichen Gesetzbuch, ed. Martin Henssler, München: C.H. Beck, 2009, Vol. IV, 10.

35 According to the BGH a SEPA-Mandat is a contract between the debtor and his bank to pay the debts of the first one (BGH 11. Zivilsenat 20/07/2010 Reference: XI ZR 236/07). Resol. of Tribunal Superior de Justicia (TSJ) of Madrid 2016/2018, 19th February \& Spanish Supreme Court (TS) 2440/2017, 15th June. The Cheque is not that different as it involves the same contractual figure; the mandat. However the payment order in this contract is issued through a cheque.

36 Resol. of Audiencia Provincial (AP) of Barcelona 9845/2017, 9th October and AP of Palma de Mallorca 972/2017, 16th May.

37 Rudi Müller-Glöhe, op. cit., 9, explains the similarities between Lease of services and the lease itself, as both contracts have the same root.

38 A lot of Franchising contracts contain agreements regarding the sale of goods Resol of BGH of 22th February 2006 (VIII ZR 40/04).

39 Rafael Natera Hidalgo, op. cit., 1061."Por confirming entendemos aquel que un establecimiento financiero se encarga de la gestión de pagos de la otra parte a sus proveedores ofreciendo estos la posibilidad de cobrar las facturas antes de la fecha de vencimiento. Tiene por objeto gestionar los pagos. Se trata de un contrato atípico, por lo que se regulará por lo establecido por las partes, por las normas del contrato de comisión y, en su caso, por 
A commercial agency contract would be a mandate given by the principal for the promotion or promotion and sale of its products, or a Spanish/German lease of services that the agent gives the principal when implementing its commercial knowledge or other figure that may encompass the kind of service provided ${ }^{40}$.

On one hand, a Joint venture contract, in which there is no creation of a new company, would have a different configuration to the joint venture agreement in which a new company is constituted through which the same is channelled since a company contract should be included in the contractual configuration ${ }^{41}$.

On the other hand, each Joint Venture contract, with or without the creation of a new company, involves several obligations, from just supplying certain products (sale of goods contract) to the collaborating company, to being involved in providing know-how or similar services (Spanish/ German lease of services).

Therefore, it would be the particular figures involved that would determine the true physiognomy of the contract and, for this purpose, its nomenclature or merely external name, would not give us a sufficiently precise legal approach ${ }^{42}$.

las normas del contrato de arrendamiento, según lo que se parte por las partes ya que la propia naturaleza del contrato dependerá de lo que se estipule por estas.”

40 Ibidem, 1187. "Al igual que los códigos de su generación, el español de 1885 no regular más contrato de colaboración que el de comisión, configurado como mandato mercantil. Sin embargo, del tronco común de la comisión han ido surgiendo otros muchos contratos de colaboración, impulsados por nuevas necesidades económicas y sociales resultantes de las transformaciones del sistema de distribución de bienes y servicios. De este modo, los nuevos contratos mercantiles han ido perfilándose en la realidad social bajo variados y, con frecuencia, imprecisos nombres, correspondiendo a los Tribunales la delicada tarea de precisar los límites tipológicos y el contenido normative”. As the $\$ 611$ (2) BGB says through the services contract one can render all kind of services including commercial ones. As we know in this case an European directive governs these specials commercial services (COUNCIL DIRECTIVE of 18 December 1986 on the coordination of the laws of the Member States relating to self-employed commercial agents (86/653/EEC). However, according to the civil law theory, the $\mathrm{CC}$ and the $\mathrm{BGB}$ can be used to complete/interpret the national transpositions of this directive.

41 Resol. AP of Girona 851/2014, 4th September and, "sensu contrario” Resol TS 1585/2012, 22th February.

42 Rafael Natera Hidalgo, op.cit, 977. 
Likewise, under the umbrella of "factoring" contracts we could find such disparate figures as the sale/assignment of rights ${ }^{43}-$ if it is a sale of credits - or the temporary sale/assignment of rights or the simple mandate to collect the customer's invoices to the factoring entity and/or a loan from the factoring entity to the customer ${ }^{44}$. It depends on whether the factoring is a real one or not (with recourse or without).

Due to this, according to civil law and the effects of the contract, the contractual classification subject to the external nomenclature, in this case, of factoring, is not so accurate. Although both figures have a similar implementation mechanism, the rules and legal effects that emerge from each figure are very different.

The time for filing a claim for non-compliance with the problems is totally different.

The outsourcing contract has normally to do with the "outsourcing" of any service ${ }^{45}$.

For example, if it were a computer outsourcing contract, this contract could consist of making softwares for the client or selling/leasing computer equipment and performing maintenance (lease of services) ${ }^{46}$ for him.

In any case it will be our civil and commercial code that regulates the core contractual figures (with all the jurisprudence and doctrine applied to these figures), the ones that will interpret that atypical institution ${ }^{47}$.

43 Resol. of BGH 21th March 2008 (VIII ZR 17/17) \& BGH 20 Dezember 2007 (IX ZR 105/07). cfr. Resol of TSJ of Andalucia, 15956/2016 of $27^{\text {th }}$ December. cfr. R. Natera Hidalgo (n 16 supra) 602.

44 Resol. of BGH 20th December 2007 (IX ZR 105/07). cfr. R. Natera Hidalgo (n 16 supra) 605. However, according to the Spanish Court Resolutions could be consider as a temporary assignment of rights (Resol TSJ of Andalucia 15956, 27 $7^{\text {th }}$ December and Resol of AP of Madrid 1247/2015, $2^{\text {nd }}$ Februar).

45 Resol. of BGH 10th May 2007 (III ZR 291/06)

46 Resol. of TSJ de Madrid, s. 5th, 3745/2015, 20th April and Resol of AP of Barcelona 6044/2015, 13th May.

47 Rafael Natera Hidalgo, op. cit., 507. "Es un contrato atípico, es decir, carece de una regulación concreta legal y, así, en defecto de pacto por las partes, será aplicable la normativa del contrato a que se asemeje, así como de forma supletoria la normativa del código civil referente a las obligaciones y los contratos. De forma sucinta está regulado por el código civil, de manera conjunta con el arrendamiento de obra y arrendamiento de cosas." 
This classification could continue like this, for example, the bill of exchange has been broken down by Garrigues ${ }^{48}$ in the mandate ${ }^{49}$, deposit, loan contracts, etc. according to its underlying relationship and it would be these main contracts that establish the consequences of the bill before its non-payment, when the specific legislation does not provide anything for this purpose.

The important thing here is to see that, for the jurist, there are no infinite contractual creations or institutions, but the features of a few key institutions are those that imprint the character and the appropriate hermeneutics to the figures later created or newly created by combining the above.

Therefore, the civil law is complete ${ }^{50}$ although it is always enriched with the various new contractual constructions.

\subsection{The growing science of law}

Civil law, instead of separating the contracts as long as they have different names, analyses the new figures under the prism of those that have already occurred in history and have been shaped by experience.

Popper said that knowledge is built on a trial-and-error learning process $^{51}$. In effect, the civil law core contracts have lived through-out the years continually improved by experience.

As described above, our mortgage has been put to the test for many centuries in the figure of its predecessor, the roman "pignus".

As we see, the commercial reality only combines the basic legal figures of the codified system and integrates them into a new contract adapted to the business needs, but, in essence, the bases and channels would already be established for civil law.

It also allows the categories or key contractual rules to be a permanent subject of study and refinement, so that the negotiating reality is simplified

48 Joaquin Garrigues, op. cit., Vol. II, 750 and 755.

49 Resol. of TS 366/2006, 17th April.

50 María José Falcón y Tella, op. cit., 63 and 111.

51 Karl Raimund Popper, La miseria del historicismo, Madrid: Alianza-Taurus, 1973, $145-158$ 
and conceptualised so that a number of different institutes, totally new and unknown, can be analysed in the light of these key contracts and their interactions.

This allows us to delve into legal science insofar that, the long-standing rules are the ones that govern with all of the jurisdiction and doctrine applied to the new figures. There will always be sales or leases but the difference will be in the form and manner in which these are carried out the basic doctrine is always applicable in all cases.

This does not deny the contribution of the new complex rules and their particular notes that increase the knowledge and interaction of the previous key institutes, but there can be no conflict with them because the latter contain the essence and basis of the legal system.

Let look at an example. Circulation of blood through the arteries and veins is based on the same physics as any aqueduct, channel or pipeline that supplies water or another liquid. Both require a pump. Although, obviously, the animal body has specialities because it is a living body, however, blood circulation is subject to the laws of physics and needs these for its physiological process.

The most rudimentary prior knowledge of physics, in this case, is essential to explain the blood circulation phenomena of living beings. Just as the doctor must know the basic laws of physics regarding vessels, pumping, gravity, etc. the trader cannot ignore civil law.

The legal scientist, fully knowing the mandate contract, can apply his knowledge to the cheque (mandate of payment to a bank), to the representative agreement (mandate), to the commercial commission (sales mandate of some goods), etc.

All new figures have their own features, which do not erase the pristine and basic substance of the mandate.

A basic figure, according to the needs of the trade, can take different configurations but this does not abrogate the previous knowledge of the figures nor contradict its known essence but it helps us to delve into it. Thus complex realities can only be understood by the study of the simplest and the analysis is a previous step for the full understanding of the contractual structures.

Furthermore, the core "civil law" contracts help the partiers, practitioner, etc. to prevent the most common conflicts which arisen from the 
praxis by properly regulating those situations. It is so, as those core contracts have been step by step enriched by the experience of centuries.

The parties are backed up by core contracts, that speed up negotiations, help them to avoid misunderstandings and prevent conflicts.

The scientist tries to understand reality based on generic classes. If there were countless new contractual rules without any relationship to the previous ones, the legal knowledge would be fleeting, temporary and changing since the former would give way to new ones, so that it would not be possible to formulate lasting general models as science does.

This explains the transfer of Roman law and its study in the faculties, as well as the survival with full force and through the centuries of its basic figures in our system, namely, the contract for sale, lease, company and mandate which were the fundamental contractual rules of Rome ${ }^{52}$.

Otherwise great literary works of good writers would not be useful, since, cyclically, they would have to be discarded and with it, we could not take advantage of knowledge.

This would prevent the jurist, a priori, from making a judgement on the new negotiating situation that is found, since it would be a newly created rule and without connection to any previous figure. However, this is not the case.

Since each basic contractual rule has a normative development in the codes, in jurisprudence (with a jurisprudential development) and in the doctrine (with a doctrinal development), all that legal wealth can help us to unravel the current reality that, only in the external aspect - but not in substance -, has varied.

And so it was in Rome where the mandate contract was applied to many different situations ${ }^{53}$. In fact, initially, the mandate was used to give security. After all, security is a mandate, in this case, given from one

52 In Rome itself the basic rules were only four, through which it was possible to channel all the business reality. See: William Warwick Buckland, Arnold McNair, op. cit., 279-280. "In Roman law, apart from certain praetorian and later pacts, of relatively small importance, there were only four contracts which were binding by mere consent, and these were, naturally, those most important in everyday commerce, sale, hire, societas (partnership) and the contract of mandatum."

53 Ibidem, 308. "But the rules of mandate itself made it useful in all manner of fields." 
person to another so that, the latter, guarantees a payment to a third party. Although the security contract has the basis of a mandate contract, to provide the third party with an action against the agent, a specific figure was also created so that the three parties were linked to each other ${ }^{54}$.

As we say, the reality will have novelties and different combinations but it will always revolve around the basic rules because selling or leasing will never stop even if they are given different names like renting, leasing, etc.

The analogy of common law seeks the same thing, that is to say, to extend to a new case the effects of a previous one so that the previous scientific work of the judge can be used in new cases. Therefore the science of law does not treat all the cases like self contained, different and independent from each other to which the science of law still does not have any answer to ${ }^{55}$.

\section{THE SCIENCE OF LAW AND CODIFIED LEGAL SYSTEM}

\subsection{The legal system as an orderly and harmonious structuring of law}

Only if we think that legal knowledge has been derived from Roman times to the present day, purifying the concentrated nectar of the main legal institutions in codes, can we speak of law as a science.

54 Ibidem, 308-309. "If I asked A to lend money to B and he did so, and B failed to repay him, A could call on me to make good his loss, since a mandator is bound to reimburse his mandatary; thus I was in effect surety for B to A, and this is in fact became a usual form of suretyship, having some advantages over the more direct forms. Again, as in the common law, rights under contract were unassignable and the device was hit upon point of appointing the intended assignee my representative (mandatory) to sue on my behalf, with exemption from any obligation to account, procuratio in rem suam."

55 However, there are times when lawyers themselves have complained about the proliferation of seemingly unrelated figures/cases, something that has happened both in Civil Law and Common Law. Ibidem 9. "Apart from the Courts of the State there are the Federal Courts, and also the Courts of other States, the decision of which though not binding are of "persuasive authority". This has led to the existence of a great unmanageable mass of case law, often conflicting, and American lawyers seem to be coming to think rather in terms of a course of decisions, a jurisprudence, like the French and German lawyers, though, in principle, in the United States as in England, a decision is binding in future cases." 
In fact, the general theory of business law, common to all contracts, does not vary and this affects their creation, fulfilment, non-fulfilment and consequences. Core concepts such as the contract for sale or lease have always, in one form or another, been present in the history of mankind and will continue to be present despite the fact that we can categorise them with other names.

The long contractual generation of recent times cannot be turned away from the law system where these business constructions must be executed or asserted. The harmony and coordination of the codified system allows, despite there being new situations, a treatment and solution to be given to them based on that knowledge that has been established and matured for centuries.

This is the accomplishment and coherence ${ }^{56}$ of any codified legal system. The accomplishment refers to the fact that the legal system is complete, that is, it can give solution to all cases, including lawsuits by nonstandard contractual rules through subsidiary regulations as we have seen. Although factoring without recourse is not standardised, because it is an assignment of credit rights, it can be guided by this legal rule.

Coherence refers to the fact that, in similar cases, the same and similar pronouncement will be given and not one that is different, since the judge is subject to the rule of law ${ }^{57}$.

Only in this way can there be true order and a legal system which is the result of long application processes and adaptation of the law to real life.

If the sale agreement contained in the leasing agreement is totally different from the regular sale, it creates an uncertainty and inconsistency in the legal system that leads to legal insecurity and legal dismemberment of the system itself. The unity of the legal system is primary and this was already defended by Kelsen, who takes it further to the point of considering a legal system as a hierarchized pyramidal organised structure ${ }^{58}$.

56 Francisco Balaguer Callejón, Fuentes del Derecho. I. Principios del ordenamiento constitucional, Madrid: Editorial Tecnos, S.A., 1991, 141 et seq.

57 The common law, based on the precedent, seeks the same coherence in judicial pronouncements.

58 According to Kelsen a system implies not only the coordination between the regulations, but these constitute a hierarchical pyramidal structure to form a whole. Hans Kelsen, La teoría pura del derecho, Buenos Aires: Eudeba, 2009, 118. 
On the other hand, law can only be science if we speak of a knowledge that, like a circle, increases its diameter, unlike a casuistic system of solutions that places the centre of the circle in different points gradually changing the reference point.

To think that each historical cycle must repeal the consolidated business rules, would mean to throw away our previous legal experience.

The sale, regardless of whether it is done orally or by email, must be based on a certain assent or acquiescence of a particular object to be able to be considered as such. Science, considered in the strict sense, cannot be subject to the changeability of its knowledge under penalty of being considered as unauthenticated.

Hence, the science of law, if it wants to be credible as such, must be based on solid and permanent foundations that shed some light on the tangled casuism of legal relations.

\subsection{Main characteristics of the codified legal system in terms of contracting}

Due to the existence of codes on which the construction and contractual hermeneutics rests, the civil law system has the following features:

a) Greater legal certainty: The whole codified system of regulations and preventions seek to promote certainty and security within the State ${ }^{59}$ so that everyone who operates knows the effects of their actions and relationships because there is an extensive set of regulations, jurisprudence and doctrine, to which the judiciary must submit, the outcome of the lawsuits can be anticipated with greater certainty.

The codification, establishing the basis or the fundamentals of the legal system, that is to say, the substantial negotiating figures and a general theory of the legal contract, allows not only a homogeneity in the treatment (since all figures that contain a mandate or a sales contract will have a common base) but due to this, it will promote security in the transactions.

In fact, when the interpretation and consequences of a given case are predictable by a homogeneous treatment, it also increases the security in

59 Victor Ehrenberg, Seguridad Jurídica y seguridad del tráfico, Madrid: Fundación beneficentia et peritia iuris, 2003, 37 . 
the contracting, as both contractors will know the exegesis to their agreement in merit to the previous codification.

Not only for the judge, notary, lawyer and jurist, is it necessary to have a list of previous contractual figures to deal properly with the new legal relations, but also for the contractors, that are in commercial practice. It is important to have common places, consolidated ways, etc. that both help them in their daily business life and grant them legal security.

Otherwise, the uncertainty and insecurity would surround the system and the judicial pronouncement would be an uncertain solution of which both parties would be shaken up.

b) Less transactions in disputes: The civil law system, on having created the basic rules in the light of which disputes and situations subject to judicial review are to be interpreted, creates a greater area of certainty (laws have been made even for the computation of damages for insurers, the compensation system, etc. ...)

Unfortunately, by adhering to these regulations, the parties, knowing that the consequences cannot transcend a certain threshold, are thrown into the legal battle without considering that an agreement or transaction out of court can be also an advisable solution.

c) Less specialization of jurists: The existence of a codified system and the primacy of civil law as the guiding principle of reality, allows lawyers to generally not have an urgent need to specialize in a very small area as there is not excessive casuism nor a proliferation of legal rules with no apparent connection between one another.

Moreover, civil law takes into account the general principles of contracting and basic legal rules in every situation. For this reason, a jurist can move, with some degree of study, in other areas that are not his own.

d) Greater coherence and unity of the system. Codification prevents that, in the solution of the case, the judgment could separate as need be from the main guidelines of the legal system. That is to say, that a claim for quantity in the civil area is totally different from a claim for commercial quantity.

As already mentioned, the system thus tends to lean towards completeness and coherence, that is to say that it gives solution to all the cases raised and that these solutions are unique and cohesive.

The problem with codified systems is that, because of the proliferation of laws and the desire to regulate everything in detail (as if the legislator 
were drawing up a judicial judgment on a case) and not rely on basic generic figures, the unit and organicism is increasingly lost and, in that "mare magnum" ${ }^{60}$ of regulations, it appears the phenomenon of the contradiction between them mentioned by Ganivet ${ }^{61}$.

Emperor Napoleon Bonaparte, the promoter of the codification movement said once: "There are so many laws, that no one is sure not to be hung" ${ }^{2}$. For this reason, gradually, from codification, we are moving to a decoding process due to the multiplicity of particular regulations on matters that have been removed from the codes, ${ }^{63}$ thus reducing the coherence and unity of the system.

In the first place the lavish regulatory creation, causes the system to revolve more in exceptions and singularities than in generic classes, what prevents the jurist to understand the legal system as it is full of casuistry and less of general concepts.

Secondly, due to the regulatory jungle, new rules created are opposed to each other and create inconsistencies in the system in the face of identical assumptions. E.g. there are different types of interest in monetary claims in the Spanish system ${ }^{64}$.

e) Less dynamism and slower adaptation of law to reality: On the other hand, in the legal system based on codification, updating is very slow and sometimes difficult. Likewise, errors are consolidated by more space.

As could not be otherwise stated, the scientist of law always lags behind contractual reality and many situations remain atypical.

60 In Spain, many of the matters that were previously in the Commercial Code, are now included in different Acts, emptying many of their content articles and leaving the regulations very dispersed. For example, the regulation in matters of Capital Companies, the regulation of Insurance matters, the regulation in matters of exchange and cheque laws, tenders, etc. This sometimes produces contradictions between one regulation and another, for example, there are various interests in different laws to regulate the same quantity claim.

${ }^{61}$ Antonio Pau Pedrón, Clarín, Ganivet, Azaña. Pensamiento y vivencia del Derecho, Madrid: Ed. Tecnos, 1994, 48.

62 Rubén Caballero Méndez, Poet@net, Poetas en la red, San Bartolomé de Tiraja, 2016, 189.

63 The law of insurance contract, bankruptcy law, exchange and cheque law, company law, etc. formerly regulated by the commercial code are currently regulated in specific laws.

64 The late payment law, the commercial code and the exchange and cheque law establish three different types of late payment interest. 
f) Shorter contractual documents. The existence of legislative references and codified figures of civil law make it unnecessary to define concepts and contractual figures in a more detailed and complete form in contracts. Hence the contracts of this system are commonly shorter and refer to the concepts of codes, e.g. damages, contract for sale, arrears, interests, etc.

Thanks to the fact that we can talk about prior legal science, the content of the contracts need not to be so lengthy, trying to anticipate all possible situations, but, they are based on the figures already integrated into our daily business relations.

Since it is impossible to foresee all the situations in the contracts, it is important to have a list of basic figures, with a vast approach, concluded and well-known, that help us to build our legal relationship.

In this way all the weight of the preparation and forecasting of the problems of the business is not left to the expertise of the parties, but it is a widely tested law that arbitrates their relations in default of an agreement, adjusting to the points that the experience has understood as more diacritic.

The existence of a rich basic contractual flow therefore generates security in the contracting, homogeneity in their application and, finally, speed in the transactions since it is not necessary to enter in all the details and possible contingencies that can happen to the commercial relationship, especially if it is a long duration agreement.

Just as it is better to write an instance from a previous model that only needs to include or take away some things according to the particular needs of the parties, having a contractual basis allows one to start from solid ground on which to adapt the contract, removing and/or putting in certain clauses, without needing to mention it or to define everything continuously.

In this sense, the brevity of clauses and contracts increase confidence and speed of contracting. Contracting must be supported by production (GDP) that enriches countries.

For example, if a cheque is not paid by the bank with funds available, we can apply the consequences of the non-fulfilment agreement by the agent of the mandate contract, with the specialties that the contractual relationship of the cheque may add. In this same case we will be able to 
use the already proven and concluded civil liability, its requirements and effects, which are common for the civil and commercial area.

Therefore, in any case, there will be always subsidiary rules that help the hermeneutics of the most complex contractual figures.

Hence, case studies will always continue to enrich legal codified knowledge by increasing the knowledge of legal science and simplifying new case studies that are always evolving but with a common core of contracting.

These studies will also be suitable for tomorrow.

\section{CONCLUSION}

It is only possible to speak of law as a science, as long as its knowledge is condensed into general institutions or concepts that permanently explain the future of legal life.

Just as physicists have condensed all physical phenomena into four fundamental laws (gravitational law, electromagnetic law, strong nuclear law, and weak nuclear law ${ }^{65}$, in which combination the most diverse phenomena occur, so every scientist of law tries to find out the general knowledge that may unravel the vast and unforeseen current contractual case studies.

The increase and accumulation of legal knowledge can only come from those general laws that are enriched when being in contact with experience.

However, if we inundate ourselves in case studies, we will think that everything is new and unknown under the sun, feeling that our knowledge is a mutable and endless mass of information where it is not possible to give any previous idea or proper way of thinking before getting to know the case in depth, as expressed by Kirchmann:

«Welche Masse von Gesetzen, und doch wie viele Lücken! welches Heer von Beamten und doch welche Langsamkeit der Rechtspflege! welcher Aufwand

65 The apparent solidity of the objects is nothing more than the result of the phenomenon of the electromagnetic repulsion that the objects make on my hand when trying to cross them, the electrical energy is but the attractive electromagnetic force between two ends, the atmospheric pressure the result of gravity attracting a column of air over the earth and the electromagnetic set of particles, etc. 
von Studien, von Gelehrsamkeit und doch welches Schwanken, welche Unsicherheit in Theorie und Praxis." ${ }^{66}$

Faced with this legal pessimism, even a layman would be better able to enhance a legal study because they are truly free of contractual prejudices that have nothing to do with the pace and negotiation of the moment.

Although Kirchmann is wrong to avoid calling law a science, as other authors do such as Kelsen ${ }^{67}$, he is right underlining the problem of regulatory prodigality which, often, because of such profusion of regulations, creates inconsistencies in the system and too many exceptions with respect to common rules ${ }^{68}$.

Although there are "few" contractual concepts, they open the door to a general understanding of the contractual world, which, although they are not completely adapt to all the nuances, they do serve to guide us when solving a particular case. As we say, the rich casuistry demands a particular study of each case but, in any case, according to the general rules.

A comparison in physics may be that of the elements of the periodic table. Knowing the properties of each one we have an indispensable propsychology for the knowledge of the matter. Although these basic elements are only 118 , their different combinations can give rise to the vast number of more than 5 million compounds with varied properties.

In this way we use lead (because of its atomic stability and density) to repel radiation, calcium is used by the bones to get strength as well as proteins (containing water and carbon) grant them elasticity.

Also, to overcome the hardness and therefore the fragility of iron to impact due to its low elasticity, carbon is included in its molecular structure making up the steel, a metal that is more resistant than the first one and better withstands the tensions.

Although each combination is new, it is still essential to study and increase our knowledge about the basic elements in order to devise better materials.

In the same manner Ihering compares Science of law to the alphabet. As he says, with twenty-six simple symbols, that even little children can

66 Julius von Kirchmann, op. cit., 8.

67 Hans Kelsen, op. cit., 82.

${ }^{68}$ Ganivet stressed the same problem as already seen. 
learn, we can build uncountable words. So it is with the Science of Law. Once we have discovered throughout the decades the basic law institutions, we can manage them more easily and draw up the most different contracts according to the needs of the parties by combining those core institutions ${ }^{69}$.

The harmonization of the legal system and its regular growth depends on solid foundations and the system cannot be diluted into a marasmus of regulations with no connection between them under the risk of not being able to manage them nor call them a legal order ${ }^{70}$.

The creativity of the jurist consists of forming, through the combination of elementary contracts, agreements that meet the aspirations of the parties. However, in observing the interaction of basic contracts, we always learn something new from these ${ }^{71}$.

69 See: Rudolf von Ihering, op. cit., 360. "Das Alphabet enthält für das Gebiet der Sprache die Lösung einer Aufgabe, die wir oben für das Recht als das Hauptproblem der Technik bezeichnet haben: die Erleichterung der Herrschaft über den Stoff durch Vereinfachung desselben, und es liegt daher sehr nahe zu fragen, ob nicht dieselbe Weise der Lösung auch hier anwendbar, die Idee des Alphabets auf das Recht übertragbar sei. Die Idee des Alphabets aber beruht auf Zersetzung, Zurückführung des Zusammengesetzten auf seine Elemente, das Alphabet ist aus der Beobachtung hervorgegangen, daß die Sprache ihren ganzen Reichtum an Worten durch eine verschiedene Kombination gewisser Grundlaute gebildet hat, und daß mithin die Entdeckung und Bezeichnung dieser Grundlaute ausreicht, um mit und aus ihnen jedes beliebige Wort zusammenzusetzen. Was die Worte in der Sprache, das sind die Rechtsverhältnisse im Recht -- die Formen, in denen die geistige Bewegung der Menschheit (Denken und Wollen) vor sich geht und sich betätigt; in Worten wie in Rechtsverhältnissen tritt das Individuum aus sich heraus und zu anderen in eine geistige Verbindung. Diese Bewegung ist aber eine unübersehbar reiche, ewig neue und produktive; jeder Tag bringt neue Worte, jeder Tag neue Rechtsverhältnisse. Aber bei letzteren wie bei ersteren ist dieser Reichtum und diese Verschiedenheit nur das Produkt einer Kombination einfacher Elemente, und hierauf beruht, wie bei der Sprache, so auch beim Recht, die Möglichkeit einer verhältnismäßig leichten Beherrschung der Sache.”

70 It is because of its 50.000 symbols, that Chinese language is one of the most difficult languages to learn \& to speak.

71 The contractual institution resulting from putting to contracts together takes into account both previous figures but it becomes a different and new contractual institution, e.g. A Leasing contract has its own particularities as the contract of sale regulations prevails over the contract of lease regulation in certain circumstances (and viceversa) (Resol of BGH 1st March 2000 (VIII ZR 177/99). 


\section{REFERENCES}

Anders, Monika, Gehle, Burkhard. 2001. Das Recht der freien Dienste Vertrag und Haftung, 2. Berlin-New York: Walter de Gruyter.

Balaguer Callejón, F. 1991. Fuentes del Derecho. I. Principios del ordenamiento constitucional, 141. Madrid: Editorial Tecnos S.A.

Buckland, Wiliam Warwick, McNair, Arnold. 2008. Roman Law and Common Law. A comparison in outline, 279-280,314-315. Cambridge: Cambridge University Press.

Caballero Méndez, Rubén. 2016. Poet@net, Poetas en la red, 189. San Bartolomé de Tiraja: RCM.

Ehrenberg, Victor. 2003. Seguridad Jurídica y seguridad del tráfico, 37. Madrid: Fundación beneficentia et peritia iuris.

Falcón y Tella, María José. 2010. La jurisprudencia en los derechos romano, anglosajón y continental, 59, 63, 111-112. Madrid: Marcial Pons.

Garrigues, J.1936 (Vol I). 1940 (Vol II). Curso de derecho mercantile, 750-755, 35. Madrid: S. Aguirre.

Guarino, Antonio. 1966. Diritto Privato Romano, 5-6. Napoli: Casa Editrice Dott. Eugenio Jovene.

Henssler, Martin ed. 2009. Münchener Kommentar zum Bürgerlichen Gesetzbuch, 9-10. München: C.H. Beck.

Ihering von, Rudolf. 1858. Geist des römischen Rechts auf den verschiedenen Stufen seiner Entwicklung, 342-354, 360, 362. Leipzig: Zweite Abteilung.

Kelsen, Hans.2009. La teoría pura del derecho, 82, 118. Buenos Aires: Eudeba.

Kirchmann von, Julius. 1973. Die Wertlosigkeit der Jurisprudenz als Wissenschaft, 8-25. Darmstadt: Wissenschaftliche Buchgesellschaft.

Natera Hidalgo, Rafael. 2012. Fiscalidad de los contratos civiles y mercantiles, 187, 602-605, 977, 1049-1050, 1061. Madrid: Grupo Wolters Kluwer.

Pau Pedrón, Antonio. 1994. Clarín, Ganivet, Azaña. Pensamiento y vivencia del Derecho, 48. Madrid: Ed. Tecnos.

Popper, Karl Raimund. 1973. La miseria del historicismo,145-158. Madrid: Alianza-Taurus.

Quintus Mucius Scaevola. 1949. Civil code commented and widely agreed and fully revised and updated by Pascual Marín Pérez, 40, 463. Madrid: Instituto Editorial Reus.

Vázquez Lépinette, Tomás. 2000. Compraventa Internacional de Mercaderías. Una visión jurisprudencial, 36-37. Navarra: Editorial Aranzadi. 